() Михайленко В. Л., Літвак А. І., УДК 614.25

DOI https://doi.org/10.31718/mep.2020.24.5-6.09

\title{
БЕЗПЕРЕРВНИЙ ПРОФЕСІЙНИЙ РОЗВИТОК - СТАВЛЕННЯ ЛІКАРІВ
}

Михайленко В. Л., ${ }^{1}$ Літвак А. І., ${ }^{2}$

${ }^{1}$ Одеський міський Центр здоров'я, м. Одеса, Україна

${ }^{2}$ Одеський регіональний інститут державного управління Національної академії державного управління, м. Одеса, Україна

Актуальність. Розвиток персоналу є неодмінним завданням будь-якої організації, як великої так і малої. В наш час професійні знання змінюються дуже стрімко, що потребує їх наполегливого поповнення і набуття нових вмінь протягом всієї професійної кар'єри. Відповідно до урядових документів (постанови Кабінету Міністрів України від 28 березня 2018 року № 302 і наказу МОЗ України № 446 від 22 лютого 2019 року) змінено правила професійної перепідготовки лікарів та їхньої атестації, заохочується більш широке запровадження сучасних форм постійної медичної освіти. Досліджень з приводу останніх нововведень ніхто не проводив, що робить представлене дослідження своєчасним і актуальним. Метою дослідження стало з'ясування думки лікарів великого міста щодо нововведень держави стосовно безперервного професійного розвитку (далі - БПР) і атестації персоналу. Матеріали і методи. Дослідження проводилося шляхом анонімного онлайн опитування (Computer Assisted Web Interviewing) лікарів міста Одеси за допомогою оригінальної анкети. Було опитано 653 лікаря комунальних закладів Одеси (21,3\% від їх кількості). Структура вибірки конгруентна за віком, статтю, лікарськими спеціальностями тощо. Результати. Лікарі у своїй більшості (понад 70\%) схвально відносяться до змін у БПР. Головними мотивами професійного саморозвитку в лікарів $\epsilon:$ прагнення до саморозвитку $(81,7 \%)$, бажання набути нових знань (88,2\%) та розширити професійні можливості (66,1\%). Лікарі проявляють себе активними і самостійними, вони надають перевагу науково-освітнім заходам, що проводяться на місцях, де вони живуть (62,6\%), та дистанційному навчанню (45,8\%), циклам тематичного удосконалення (62,1\%). Лікарі первинної ланки виявили більш високу активність в питаннях БПР. Гострим питанням є фінансова складова. Висновки. Для успішного продовження інновацій в системі БПР в Україні необхідна комплексна програма підтримки лікарів, основними партнерами яких мають стати МОЗ України, органи місцевого самоврядування, лікарські асоціації і товариства, а також відповідальний бізнес.

Ключові слова: безперервний професійний розвиток, постійна медична освіта, самооцінка, атестація, фінансування

Relevance. Staff development is an essential task of any organization, both large and small. Nowadays, professional knowledge is changing very rapidly, which requires persistent replenishment and acquisition of new skills throughout the professional career. In accordance with government documents (resolution of the Cabinet of Ministers of Ukraine as of March 28, 2018 № 302 and order of the Ministry of Public Health of Ukraine as of February 22, 2019 № 446), which changed the rules of professional retraining of doctors and their certification, wider introduction of modern forms of continuing medical education are encouraged. No research on the latest innovations has been conducted yet, which determines the timeliness of the present study. The aim of the study was to find out the opinion of doctors in a large city about the state's innovations regarding continuous professional development (CPD) and staff certification. Materials and methods. The study was conducted through the anonymous on-line survey (Computer Assisted Web Interviewing) of doctors in Odesa using the original questionnaire. The number of respondents were 653 (public medical facilities of Odesa). The sample structure was congruent by age, sex, medical specialties, etc. Results. Most doctors (over $70 \%)$ approve of changes in CPD. The main motives for CPD of doctors are striving for self-development (81.7\%), the desire to acquire new knowledge (88.2\%) as well as expand professional opportunities (66.1\%). Doctors demonstrated their attitude as active and independent specialists, they prefer scientific and educational activities conducted in the places where they live (62.6\%), as well as distance learning (45.8\%), cycles of thematic improvement (62.1\%). Primary care physicians have manifested greater activity in CPD issues. The financial component is an acute issue. Conclusions. For the successful continuation of innovations in CPD system in Ukraine, a comprehensive program of support for physicians is needed. The main partners in this should be the Ministry of Public Health of Ukraine, local governments, medical associations and societies, as well as a responsible business structure.

Keywords: continuing professional development, continuing medical education, self-assessment, certification, funding

\section{Вступ}

Персонал організації є її золотим фондом, від якого залежать досягнення та існування організації. Розвиток персоналу $є$ неодмінним завданням будь-якої організації, як великої, так і малої. Науково-технічний прогрес змінює професійні знання працівників дуже стрімко. Як засвідчують спеціалісти, знання випускників навчальних закладів професійної освіти на початку минулого століття майже повністю змінювались через 30 років. Наприкінці $X X$ століття цей період зменшився втричі - до 10 років. Тепер це 3-5 років. Бути доб-

\footnotetext{
* Цитування при атестації кадрів: Михайленко В. Л., Літвак А. І., Безперервний профресійний розвиток - ставлення лікарів. // Проблеми екології і медицини. - 2020. - T. 24, № 5-6. - С. 32-38.
} 
рим лікарем значить постійного і наполегливого протягом усієї професійної кар'єри поповнювати і оновлювати арсенал своїх знань, навичок і вмінь - всього того, що визначено як безперервний професійний розвиток (далі - БПР) [3, 6].

До основних форм безперервного професійного розвитку лікарів відповідно до постанови Уряду належать: участь у тематичних школах, семінарах, науково-практичних конференціях, конгресах, симпозіумах, з'їздах, у симуляційних тренінгах, майстер-класах, курсах $з$ оволодіння практичними навичками, медичне стажування за межами закладу, де працює фахівець, дистанційне навчання, у тому числі з використанням електронних навчальних ресурсів, навчання на циклах тематичного удосконалення в закладах (на факультетах) післядипломної освіти тощо $[1,2,4]$. Згідно наказу МОЗ України, з 01.01.2020p. змінюються правила професійної перепідготовки лікарів та їхньої атестації [5].

Проблеми професійного розвитку відображені у дослідженнях багатьох авторів: О. І. Бульвінської, В. М. Гриньової, Р. Б. Грицко, А. П. Егоршина, А. Я. Кібанова, В. Г. Кременя, С. М. Маркової, Л. П. Пуховської, Г. О. Слабкого, В. А. Співак, Ф. І. Хміля, І. М. Хоржевської та інших. Разом з тим, досліджень з приводу останніх змін і нововведень для лікарів за доступними даними ще ніхто не проводив, що робить це опитування актуальним і своєчасним.

Метою дослідження стало з'ясування думки лікарів щодо нововведень в сфері безперервного професійного розвитку і атестації на визначення кваліфікаційних категорій. Об'єктом дослідження виступив медичний персонал великого міста в країні, а його предметом стала думка лікарів про різні аспекти нового порядку забезпечення і контролю безперервного професійного розвитку лікарів на прикладі міста Одеса. Дослідження проводилося на замовлення департаменту охорони здоров'я Одеської міської ради з 05 по 21 червня 2020 року.

\section{Матеріали та методи дослідження}

Всього до опитування долучилися 653 респонденти, тобто, 21,3\% від усіх лікарів муніципальних медичних закладів міста Одеси. Дослідження проводилося шляхом анонімного онлайн опитування лікарів (96\% опитаних) зазначених закладів за допомогою оригінальної анкети, розробленої фрахівцями КУ Одеський міський Центр здоров'я» та експертами Одеської крайової організації ГО «Всеукраїнське Лікарське Товариство». Онлайн-опитування (Computer Assisted Web Interviewing - CAWI) широко використовується в галузевих дослідженнях як кількісний метод збору інформації і є методом цілком релевантним щодо мети дослідження.

Анкета містила 27 запитань з різноманітними варіантами відповідей, серед яких кожен респондент обирав свій. Питання стосувалися різних напрямків діяльності, пов'язаних із БПР: особистого відношення лікарів до змін, які відбуваються, і необхідності атес- тації персоналу; особистої активності наших респондентів в питаннях БПР, планування освітньої діяльності і набору необхідних балів щорічно; оцінка стану справ в цій царині в закладах охорони здоров'я і ролі адміністрації закладу; джерел і можливостей фрінансування діяльності, пов'язаною з БПР, тощо. Більша частина запитань передбачала лише одну відповідь, решта питань дозволяла вибір кількох відповідей. Таких запитань було десять, вони стосувалися участі в освітніх заходах, джерел професійної інформації, місця роботи, лікарської спеціальності, наукового звання. Відповідь на сім запитань була обов'язковою: крім віку, всі вони стосувалися актуальної діяльності лікаря та його закладу в плануванні БПР.

Анкета була підготовлена за допомогою «Google form», опрацювання даних здійснювалось за допомогою Google-таблиць та Excel. Опитування проводилось виключно в онлайн режимі, анонімно. Дані дослідження є достатньо репрезентативними, як за кількістю, так і за іншими параметрами.

Структура вибірки. Як видно з даних опитування, до нього долучились різні за віком і статтю люди, що достатньо коректно відбиває віковий і статевий зріз всієї лікарської спільноти міста. Майже три чверті опитаних були жіночої статі $(73,4 \%)$, кожен п'ятий $(20,8 \%)$ - чоловічої. Знайшлись і такі, що не схотіли повідомити про свою стать. Їх було 35 осіб (5,4\%). На розподіл за статтю могла вплинути більш активна участь в опитуванні лікарів первинної ланки і дитячих медичних закладів. Половина респондентів (49,6\%) були у найбільш продуктивному в професійному плані віці - 41-60 років. Кожен п'ятий респондент був пенсійного віку (від 61 до 70 років - 18,8\%). Віком 31-35 років було $11 \%$ респондентів, у віці $36-40$ років - 8,6\%, до 30 років, тобто молодих спеціалістів, було 9,6\%. Загалом на репрезентативність даних досліджень могло також вплинути, що в досліджені, вірогідно, взяли участь більш підготовлені і вмотивовані лікарі.

Абсолютна більшість опитаних - 83,9\% - були практикуючими лікарями. Кожен десятий респондент $(11,9 \%)$ займав посаду завідуючого структурним підрозділом. Ще 3\%, або 19 респондентів, були заступниками керівника закладу охорони здоров'я. В опитуванні взяли участь також 4 керівника медичного закладу (діаграма 1).

Опитані лікарі працюють у різних закладах, що утворюють мережу амбулаторної і стаціонарної медичної допомоги, це є лікарі, що зайняті допомогою дітям і дорослим, як в первинній ланці медичної допомоги, так і в консультативно-діагностичних центрах та лікарнях міста (діаграма 2). Найбільш активними були лікарі первинної ланки і особливо педіатри, що цілком вірогідно свідчить про їх більш високу активність в сфрері постійної медичної освіти . 


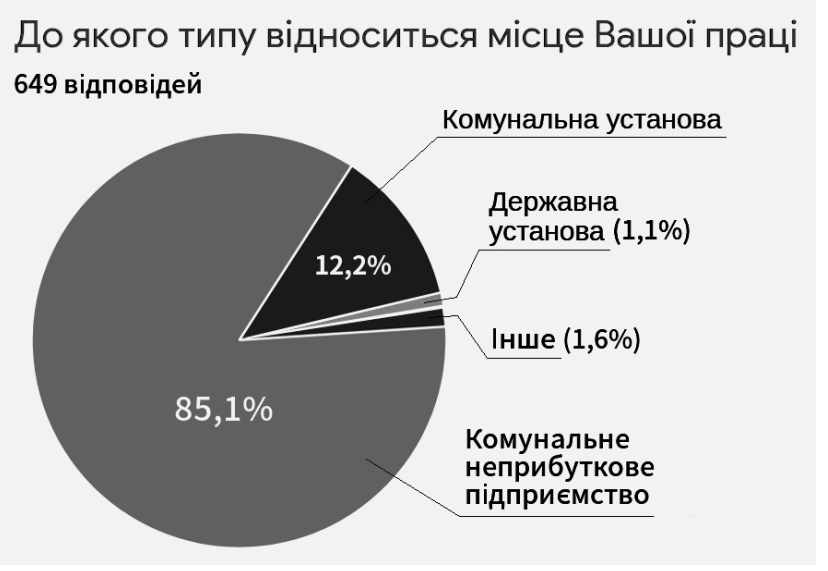

Діаграма 1. Тип закладу

Результати та їх обговорення

Професійна освітня активність і кваліфікація. Дані дослідження свідчать, що в опитувані взяли участь лікарі переважно з високою фраховою підготовкою, яка визнана державою через механізм атестації:

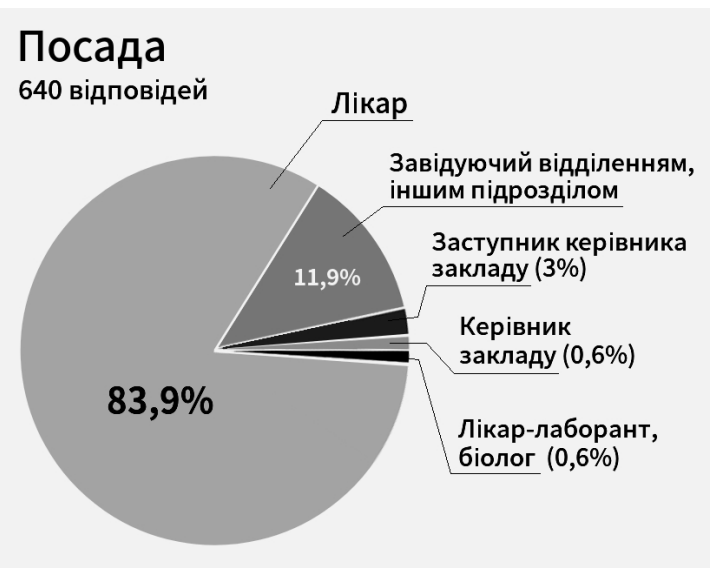

Діаграма 2. Посада

$62,5 \%$ опитаних мають вищу атестаційну категорію, ще 5,6\% мають вищу категорію за двома спеціальностями, $11,1 \%$ першу, і лише $12,4 \%$, це переважно молоді спеціалісти і деяка частина лікарів-пенсіонерів, не мають жодної категорії (діаграма 3).

Яку кваліфікаційну категорію/категорії Ви маєте на цей час? (можна дати кілька відповідей, якщо категорії різняться за спеціальностями) 647 відповідей

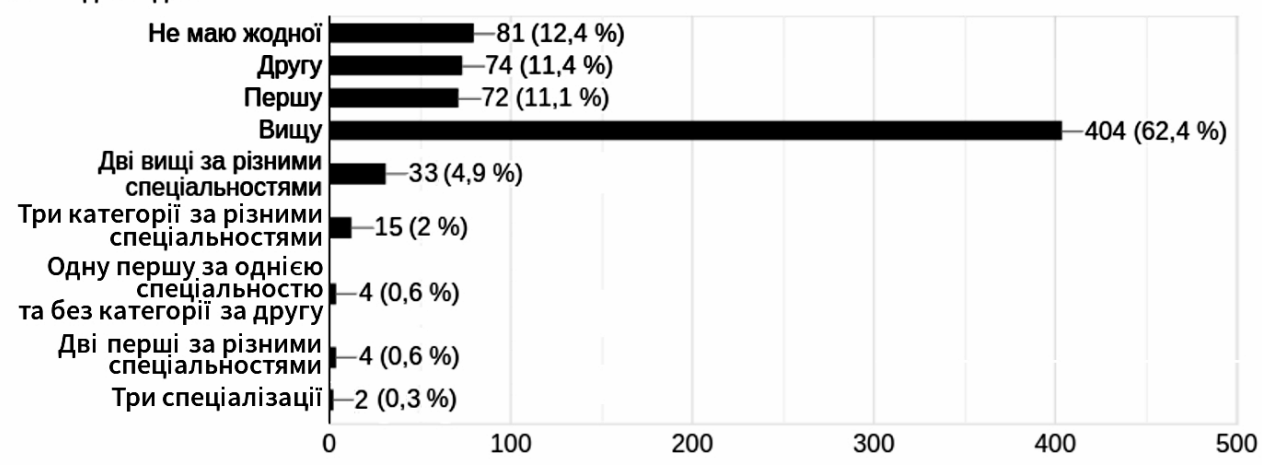

Діаграма 3. Кваліфрікаційні категорії

Формальне визнання кваліфрікації добре корелює із самооцінкою респондентів (діаграма 4). Дизайн опитування спеціально передбачав особисту оцінку свого профресіоналізму. Вважається, що люди, які оцінюють самі себе, рідко висловлюють свою особисту оцінку вище ніж таку, що є публічною думкою.

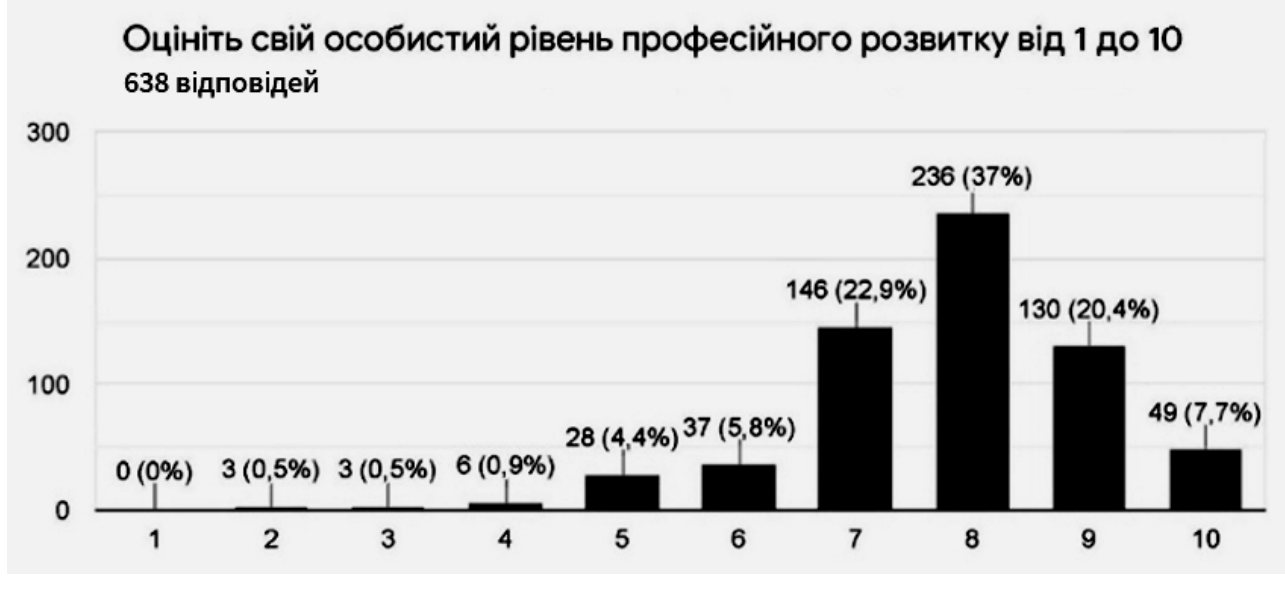

Діаграма 4. Самооцінка професійного розвитку

Хоча дисперсія самооцінок була в діапазоні від 2,0 до 10,0, балів самооцінка у вісім балів була найбільш популярною серед опитаних лікарів, таких було $36,9 \%$. На другому місті була група лікарів, які оцінили себе на сім балів - 22,9\%, а останнє призове місце за кількістю зайняла група лікарів, які оцінили свої професійні здібності у дев'ять балів, їх було 20,4\%. Екстра спеціалісти із самооцінкою в десять балів утворили наступну групу $-7,7 \%$. Цікаво, що дві групи з найвищими оцінками (9 і 10 балів) разом складають майже 
у двічі меншу долю, ніж доля осіб із вищою атестаційною категорією.

На питання «Що спонукає вас до професійної самоосвіти?», відповіді на яке ссрормульовано так, що вони проявляють мотиви стосовно БПР: 87,7 \% респондентів вибрали відповідь: «отримання нових знань». 81,3\% - «особистий та професійний зріст». 66,3\% «розширення професійних можливостей».

Відповідь, пов'язану із підвищенням заробітної плати обрали лише 84 респонденти - 12,9\%. Отже, основними мотивами щодо БПР є прагнення лікарів до профресійного розвитку і успіху, бажання постійно вчитися. Це $є$, головним чином, внутрішні мотиви розвитку людини і лише незначна частка респондентів, кожен восьмий, орієнтована на зовнішні мотиви, до яких відноситься заробітна плата і ії̈ зростання. Маємо дилему, чи є ці відповіді відображенням внутрішнього прийняття «ідеалу лікаря», чи вони віддзеркалюють практичний досвід, який свідчить що між знаннями і професіоналізмом та заробітками лікаря зв'язок відсутній, або ж і те і інше (діаграма 5).

\section{Що спонукає Вас до постійного професійного самоосвіти? Можна дати кілька відповідей, але не більше 3-х.}

652 відповіді

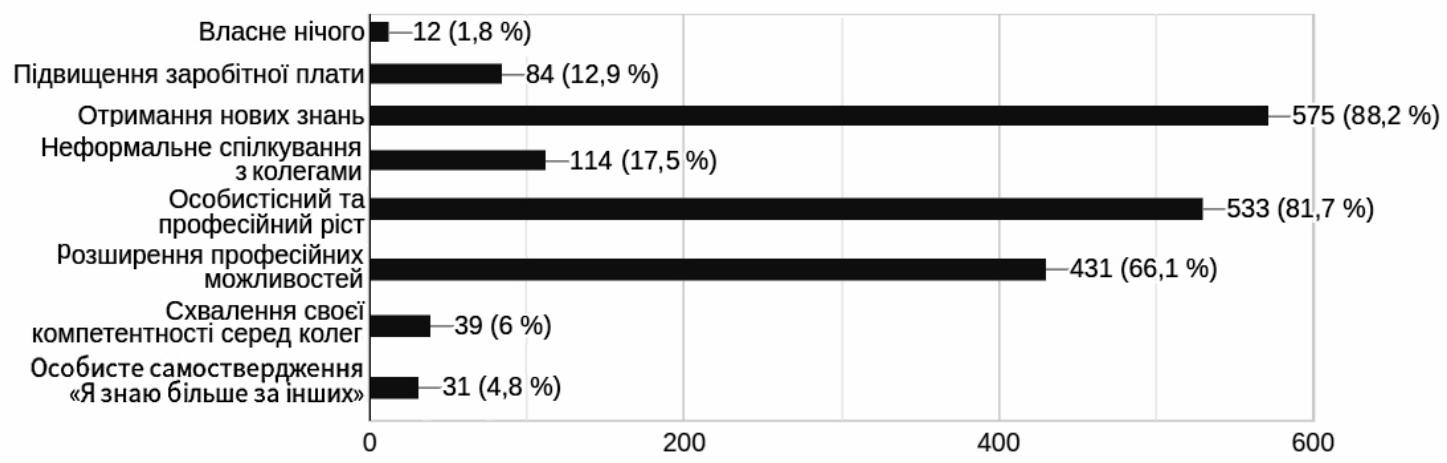

Діаграма 5. Мотивація до професійного розвитку

Джерела професійної інформації і рівень участі в наукових заходах прояснювалися кількома запитаннями. На питання «Чи брали ви участь в міжнародних медичних конференціях або заходах за кордоном?» більшість респондентів дали негативну відповідь, лише кожен п'ятий (19,5\%) опитаний лікар брав участь у подібних заходах хоча б раз за останні п'ять років і лише 43 респонденти $(6,3 \%)$ зазначили, що в подібних заходах брали участь тричі і більше протягом останніх п'яти років.

Таким чином, серед лікарів поки що не стало правилом їхати за кордон на з"їзди і конференції з метою удосконалення своїх знань, що вочевидь має в першу чергу фрінансове підґрунтя і $€$ ще одним підтвердженням низького соціально-економічного статусу лікарів в нашій країні. Цей факт слід враховувати і створювати відповідні можливості в нас в країні, залучаючи до цього відомих вчених провідних іноземних фрахівців.

На питання «Чи брали ви участь в наукових заходах в Україні?» спектр відповідей був набагато шир-

чи брали Ви участь за останні п'ять років в наукових заходах: медичних конференціях або з'їздах, конгресах, що проводилися в Україні?

651 відповідь

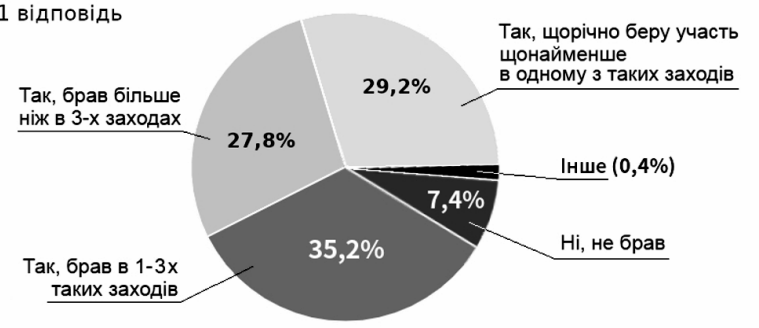

Діаграма 6. Участь в науково-освітніх заходах в Україні

Найбільш важливим джерелом професійної інфрормації наші респонденти вважають місцеві конференції, з ними конкурують курси тематичного удоскона- ший. Більше всього (35,3\%) респондентів відповіли, що вони приймали участь в подібних заходах одинтри рази протягом останніх п'яти років. $29 \%$ респондентів відзначили, що вони щорічно беруть участь в подібних заходах. 27,9\% респондентів зазначили, що протягом року вони тричі приймали участь в подібних публічних заходах. Лише 48 осіб (7\%) відповіли, що взагалі не брали участь в подібних заходах. Таким чином, відповіді наших респондентів засвідчують популярність серед лікарів суспільних заходів науковоосвітнього характеру, які не потребують далеких подорожей, а від того і менше коштують. Але необхідно звернути увагу на слабку ланку, яка взагалі лишається поза заходами науково-освітнього характеру, що проходять в нашій країні. Це 7\% респондентів, і треба думати, цей відсоток все ж таки значно вищий серед тих, хто не взяв участь в опитуванні, а їм також потрібна участь в наукових заходах для свого професійного зростання (діаграми 6 i7).

Чи брали Ви участь за останні п'ять років в наукових заходах: медичних конференціях або з'їздах, конгресах, що проводилися за кордоном?

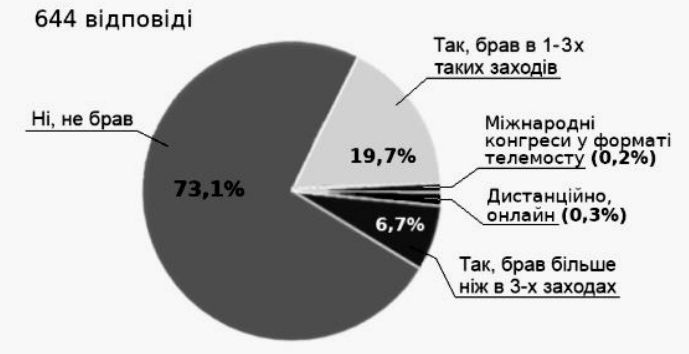

Діаграма 7. Участь в науково-освітніх заходах за кордоном лення (62,6\% і $62,1 \%$ респондентів відповідно) національні конференції, з"їзди, конгреси наші респонденти підняли на третє місце $(51,3 \%)$. Понад третина респо- 
ндентів $(37,9 \%)$ удосконалюється за рахунок читання професійних журналів по спеціальності, що на нашу думку, не є достатнім для сучасних лікарів. Майже половина респондентів зазначили як джерела медич- ної інфрормації і свого професійного розвитку Інтернет і дистанційне навчання - 46,2\% і 45,6\% відповідно (діаграма 8).

\section{3 перерахованих нижче джерел професійної інформації виберіть три найбільш важливих для Вас, якими Ви користуєтеся найчастіше:}

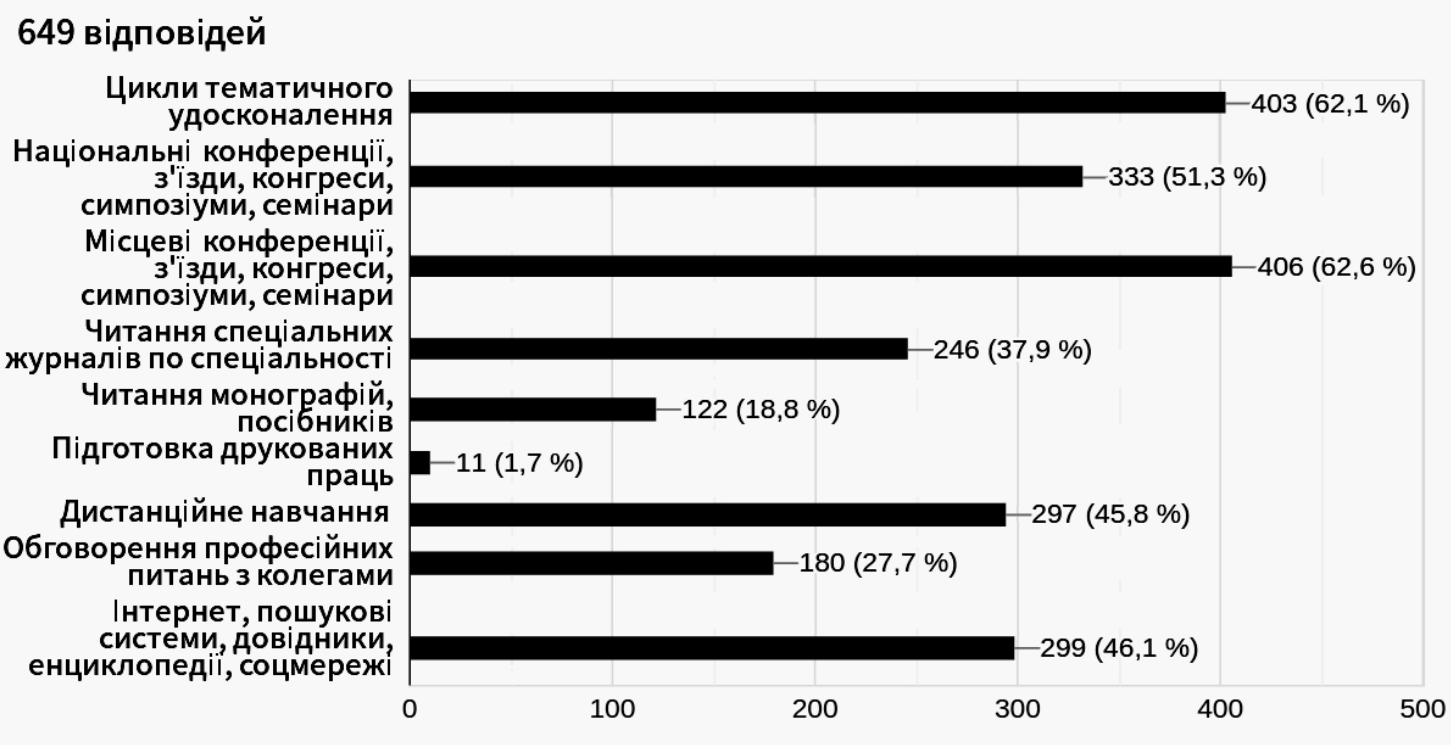

Діаграма 8. Джерела професійної інфрормації

Два запитання стосувалися планування і кількісних показників освітньої активності. На питання «Як ви плануєте свій профресійний розвиток?» більшість, це майже дві третини респондентів (61,1\%), відповіли, що роблять це самостійно, підбираючи підходящі заходи. Ще третина респондентів $(36,6 \%)$ підбирають заходи в залежності від обставин. Таким чином, вибір заходів із БПР лікарями відбувається виключно самостійно за їхнім бажанням і особистою зацікавленістю.

Понад третина респондентів (37,6\%) повідомила, що мають понад 50 балів, тобто вже досягли встановленого державою річного мінімуму. Кожен сьомий $(16,1 \%)$ респондент накопичив від 41до 50 балів, а майже кожен десятий має $31-40$ балів $(8,6 \%)$ і 21-30 балів $(10,1 \%)$. Ще дві децилі утворюють ті, хто мають 11-20 балів $(10,1 \%)$ i 1-10 балів $(10,0 \%)$ відповідно. Були й такі респонденти, що мають нульовий результат. Серед опитаних таких виявилась 41 особа - 6,4\%, а в дійсності таких людей може бути і більше, оскільки сам фракт участі в опитуванні свідчить про більш високу мотивацію, поінформованість і активність.

Окремий блок запитань стосувався ролі керівництва закладів в плануванні, організації та фрінансуванні БПР. Відповідно до чинної нормативно-правової бази обов'язок забезпечити належні умови для БПР працівника, в тому числі його фрінансування, покладається на працедавця, отже кошти на БПР лікаря мають бути передбачені у фрінансових планах медичних закладах, але широкому загалу це невідомо. Лікарі також не відають, як цими коштами можна скористатися, який порядок їх отримання, а громадські органі- зації і, в першу чергу, профспілки на цьому не наполягають, хоча відповідно до законодавства вони мають i такі повноваження, і таку відповідальність. У відповідності до постанови Кабміну Міністрів України № 302 від 28.03.2020p. «фінансування безперервного професійного розвитку фахівців у сфері охорони здоров'я здійснюється за рахунок бюджетних коштів у порядку, затвердженому МО3 України з урахуванням принципу індивідуального виділення фіксованої суми коштів на безперервний професійний розвиток окремого лікаря, а також за рахунок коштів фрізичних та/або юридичних осіб та інших не заборонених законодавством джерел фрінансування».

Тому окреме питання стосувалося поінформованості лікарів про фрінансову підтримку роботодавцем заходів БПР. Як показали відповіді: понад три чверті $(76,2 \%)$ нічого про це не знають, 10,3\% відповіли більш відверто, що на це кошти не заплановані, $7,7 \%$ відповіли, що щось $€$, але невідомо, як цим можна скористатися, і лише $5,5 \%$ респондентів відзначили, що у фінплані закладу є окремий рядок, який це передбачає (не виключено, що такі інформовані лікарі можуть належати до адміністраторів).

На питання «В чому може бути підтримка БПР з боку працедавця?» респонденти обрали наступні відповіді: понад третина респондентів вважають вже достатньою підтримкою збереження заробітної плати на час навчання, а також можливість сплати декому за навчання на курсах 3 тематичного удосконалення (36\% і 34,5\% респондентів відповідно), але кожен четвертий $(25,3 \%)$ респондент на це зовсім не розраховує (діаграми 9, 10). 
Чи знаєте Ви про факт і розмір коштів виділених Вашим працедавцем на постійний професійний розвиток медичного персоналу?

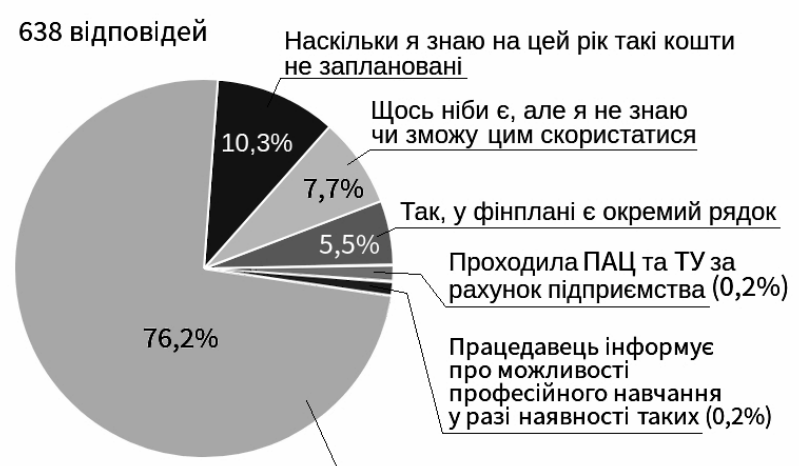

Нi, я нічого про це не знаю

\section{Діаграма 9. Виділення коштів на фрінансування БПР працедавцем}

На питання «Чи можете ви розраховувати на допомогу фрармфрірм?» були отримані різні відповіді. $41,2 \%$ респондентів вважають, що це можливо, але за певних умов. Майже стільки ж людей $(38,9 \%)$ надали зовсім протилежну відповідь «ні, це неможливо». Тільки кожен п'ятий респондент $(19,3 \%)$ відповів на це запитання позитивно і активно цими можливостями користується. 3 огляду на складні етичні питання, що постають в разі такої допомоги, це питання потребує особливої уваги і додаткового вивчення (діаграма 11).

На питання «Яку суму грошей вашого особистого доходу ви готові витратити на самоосвіту і підвищення кваліфрікації?» були отримані такі відповіді (діаграма 12):

- $\quad$ кожен шостий чи сьомий респондент $(15,5 \%)$ відповів, що в нього немає ніякої можливості це зробити;

Чи можете Ви розраховувати/вже користувалися допомогою з боку фармацевтичних фірм або інших спонсорів

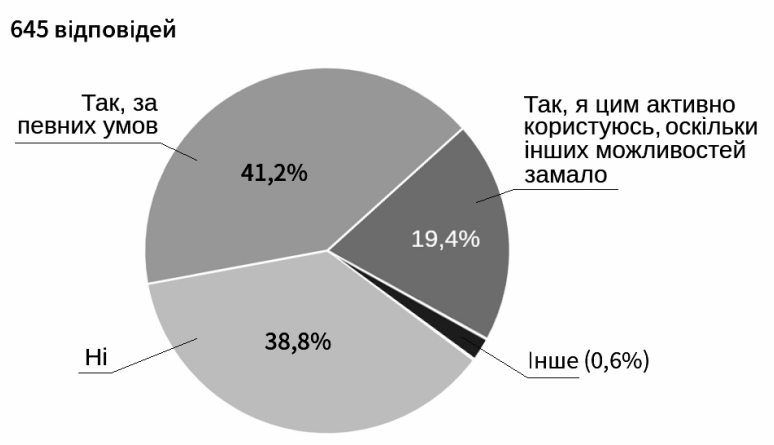

Діаграма 11 Як розраховують лікарі допомогу з боку фрармфірм

На питання «яке ваше ставлення до змін у системі БПР?» більшість респондентів (70\%) відповіли, що вважають це позитивним кроком, але деякі респонденти мають застереження про поспішність, 3
Чи можете Ви розраховувати на оплату Вашої подальшої медичної освіти/безперервного професійного розвитку за рахунок працедавця (може бути кілька відповідей)

643 відповіді

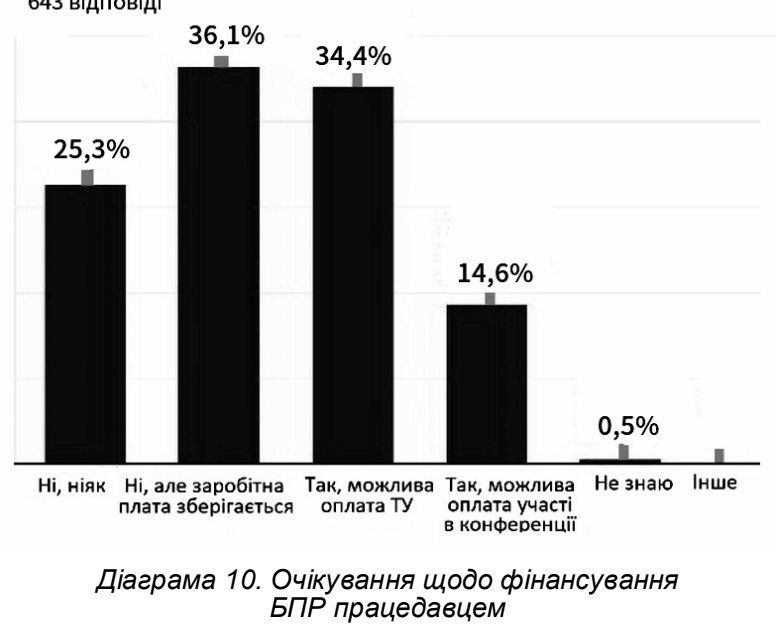

- кожен четвертий респондент (23\%) заявив, що це може бути не більше 1,0\% його особистого доходу;

- $\quad$ разом з тим кожен третій лікар (35,7\%) погодився витратити на ці цілі до 5,0\% свого доходу;

- $\quad$ ще кожен п'ятий респондент $(18,7 \%)$ готовий віддати на цю справу трохи більше грошей, до 10\% свого доходу;

- $\quad$ і хоч це виглядає досить несподівано, $є$ також лікарі, які готові витратити на своє удосконалення більше $10 \%$ відсотків свого доходу. Це відносно невелика кількість (7,6\%), але вона означає, що є лікарі, які в своєму прагненні до профресійного зростання готові жертвувати суттєву долю свого скудного заробітку.

\section{Сума грошей з особистого доходу, яку лікар готовий витрачати на заходи БПР}

646 відповідей

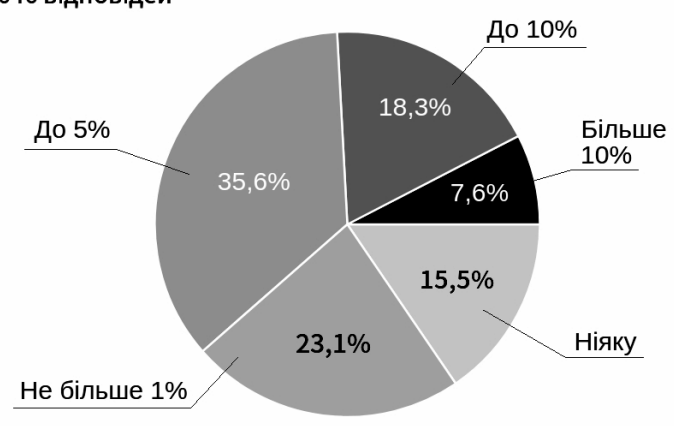

Діаграма 12. Готовність до витрат із власного бюджету (\% від доходу)

якою це робиться. А кожен третій респондент $(33,4 \%)$ вважає за можливе взагалі скасування атестаційних категорій (діаграма 13). 
Ваше ставлення до змін в системі професійного розвитку. Можна дати кілька відповідей, але не більше трьох 646 відповідей

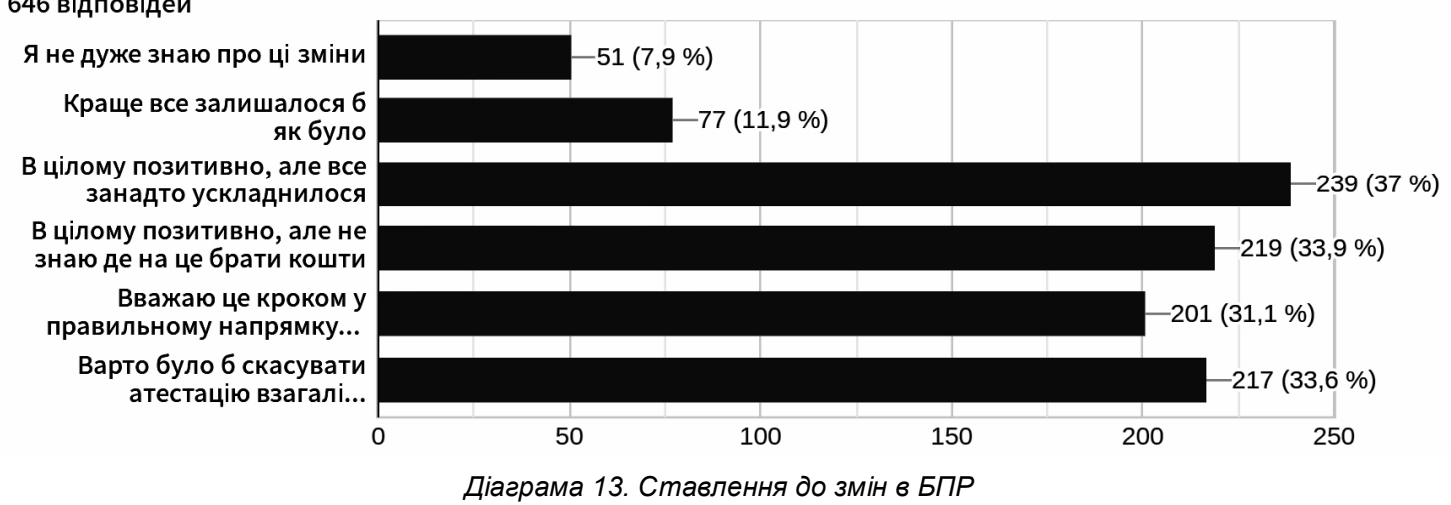

Разом з тим, є і протилежні думки - 12\% респондентів вважають, що було б краще, якщо все залишилось би, як було раніше, ще 7,9\% респондентів зазначили, що вони не дуже в темі і не розуміють, що відбувається в питаннях БПР.

Як бачимо, спектр думок про БПР достатньо широкий. Але більшість респондентів на першому етапі змін підтримує той курс, що втілюється.

\section{Висновки}

Підсумовуючи отримані результати можна стверджувати:

1. Лікарська громадськість у своїй більшості схвально відноситься до змін у БПР. Разом з тим, певний негативізм в цьому питанні проявив кожний п'ятий лікар, і це є свідченням недостатньої поінформованості медичного персоналу та несистемності в діях керівництва медичних закладів і владних структур.

2. Головними мотивами професійного саморозвитку у значної більшості лікарів є внутрішнє бажання і прагнення до саморозвитку, бажання набути нових знань, розширити свої професійні можливості. Фінансова мотиваційна складова $є$ невиправдано низькою.

3. Лікарі у своїй більшості проявляють себе активними і самостійними, намагаються вирішити по можливості проблеми і питання БПР, які перед ними постають. Вони надають перевагу науково-освітнім заходам, що проводяться на місцях, де вони живуть і працюють, а також дистанційному навчанню. Отже, орієнтуючись на інтереси, потреби і можливості лікарів, слід активно використовувати і розвивати ці форми постійної медичної освіти (далі - ПМО).

4. Більш висока активність в питаннях БПР, як і в опитуванні в цілому, лікарів первинної ланки може свідчити про їх більшу вмотивованість до праці в охороні здоров'я. Проте не виключено, що це обумовлено специфрікою вибірки або тим, що лікарі первинної ланки довший час були залучені до інших процесів реформування і краще призвичаїлися до сучасних засобів комунікації, зокрема до онлайн опитувань.

5. Гострим і фактично невирішеним питанням $€$ фінансова підтримка БПР лікарів, оскільки більшість 3 них не мають достатніх коштів, щоб самотужки вирішити питання свого професійного розвитку, і на значне підвищення заробітків лікарів ближчим часом розраховувати не доводиться. Лікарі потребують дієвої підтримки з боку відповідального працедавця і залучення до цієї справи партнерів і кооперації різних інституцій.
6. Питання БПР мають бути у фокусі уваги керівників медичних закладів, включати дієві управлінські заходи, бути публічними і зрозумілими для медичного персоналу. На часі є розробка і запровадження на засадах соціального партнерства програм для підтримки безперервного професійного розвитку лікарів. Основними партнерами для лікарів мають стати МO3 України, органи місцевого самоврядування, лікарські асоціації та товариства. Важливо добитися долучення до цих програм соціально відповідального бізнесу, зокрема, фрармацевтичної індустрії.

\section{Перспективи подальших досліджень}

Опитування та інші інструменти соціологічних досліджень про важливі зміни і напрямки розвитку в системі охороні здоров'я $€$ важливим засобом визначення стану проблеми, і хоча дані цього дослідження досить сміливо можна екстраполювати на національний рівень, варто думати про проведення всеукраїнського опитування щодо питань постійної медичної освіти і безперервного професійного розвитку лікарів.

Конфрлікт інтересів. Автори заявляють про відсутність конфолікту інтересів.

\section{Література}

1. Андрух В.С, Андрух В.Н., Слободян М.В. (2019). Сучасні аспекти безперервного професійного розвитку лікарів у сфері охорони здоров'я України.

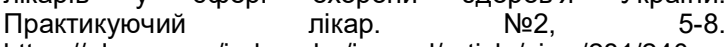
https://plr.com.ua/index.php/journal/article/view/281/240

2. Безперервний професійний розвиток: куди підуть «гроші за лікарем»? Інтерв'ю з проректором 3 науковопедагогічної роботи НМАПО імені П. Л. Шупика, професором Олександром Толстановим. Ваше Здоров'я, 27.01.20 p. URL https://www.vz.kiev.ua/bezperervnyjprofesijnyj-rozvytok-kudy-pidut-groshi-za-likarem/

3. Безперервний професійний розвиток лікарів у 2020 році. Потупалова Т.О. Сайт МО3 https://www.medsprava.com.ua/files/Articles\%20MEDSPR AVA/1895/bpr.pdf

4. Вороненко Ю. В., Мінцер О. П. (2017). Логіка використання портфоліо в забезпеченні якості післядипломної медичної освіти та безперервного професійного розвитку лікаря. Аналітичний огляд. Медична інформатика та інженерія. № 3, 5-13

5. «Про деякі питання безперервного розвитку лікарів». Наказ МО3 України № 446 від 22.02. 2019 р. URL: https://zakon.rada.gov.ua/laws/show/z0293-19\#Text

6. «Про затвердження «Положення про систему безперервного професійного розвитку фахівців у сфері охорони здоров'я» Постанова КМ України від 28 березня 2018 № $302 . \quad$ URL: https://zakon.rada.gov.ua/laws/show/302-2018-\%D0\%BF Матеріал надійшов до редакції 07.10.2020 